\title{
繊維強化プラスチック材料の振動減衰同定に及ぼす大気圧の影響*
}

$$
\begin{array}{lllll}
\text { 座 古 } & \text { 勝*1, 松 本 金 } \text { 矢 }^{* 2} \\
\text { 倉 敷 哲 } & \text { 生*1, 中 西 康 } \text { 雅*2 }^{* 1}
\end{array}
$$

\section{An Influence of Atmosphere on Identification Method of Vibration Damping Parameters for Fiber Reinforced Plastics}

\author{
Masaru ZAKO*3, Kin'ya MATSUMOTO, \\ Tetsusei KURASHIKI and Yasumasa NAKANISHI \\ ${ }^{* 3}$ Department of Management of Industry and Technology, Osaka University, \\ 2-1 Yamadaoka, Suita-shi, Osaka, 565-0871 Japan
}

\begin{abstract}
An effect of the air on the material damping of fiber reinforced plastics has been investigated. As the most of vibration tests are carried out in the atmosphere, however, the material damping has not been evaluated with accuracy. The vibration tests of CFRP plates have been carried out in the atmospheric pressure and in the low-pressure conditions, respectively. Comparing the both of experimental results, the effects of an atmosphere on the natural frequency and damping have been discussed. From these experimental results, it is revealed that the aerodynamic force has a great influence on the damping ratio and the test at below $10^{3} \mathrm{~Pa}$ needs to obtain the real damping ratio. On the other hand, there is little effect of the air on the natural frequency. The damping parameters of CFRP are also identified by the experimental result. These results show that it is important to take the effect of the air on the damping into consideration.
\end{abstract}

Key Words: Vibration, Damping, Composite Materials, Identification, Vacuum

\section{1. 緒 言}

繊維強化複合材料は軽量で，比剛性，比強度に優れ ており，材料設計が可能であることから多くの工業分 野で利用されている．特に宇宙空間において構造物の 振動を抑制する必要性から，高減衰特性を有する絩維 強化複合材料は宇宙航空分野で不可欠な構造材料であ る. 構造物の振動制御を行うためには，紼維強化複合 材料自体の振動減衰特性を把握し，それらを考虑した 材料・構造設計が重要である.

これに対し，纎維強化複合材料の振動減衰性能を 評価する目的で多くの研究が行われてきた (1) (11). そ の中で，振動減衰特性評価に最もよく用いられるのが Adams らのひずみエネルギ理論である. Adams らはひ ずみエネルギ理論を用い，解析結果と試験結果が一致 することを示している(2)(3). また有限要素法をもとに した振動減衰モデルの定式化を行い，積層板に適用し， その有効性を示している(4).この振動減衰モデルによ れば，絾維強化複合材料積層板を構成するラミナの減 衰定数を用いて，積層板および繊維強化複合材料構造

* 原稿受付 2004 年 3 月 30 日.

*1 正員, 大阪大学大学院工学研究科(565-0871 吹田市山田 丘 2-1).

*2 正員, 三重大学教育学部(⑤14-8507 津市上浜町 1515).

E-mail : zako@mapse.eng.osaka-u.ac.jp
物の振動減衰特性を評価することができる。この Adams らの振動减衰に関する研究をもとに，青木らは CF/PEEK 積層材の振動試験を行い，減衰能を算出して いる( ). 足立らは自由支持法と片持ち梁法で振動試験 を行い，ひずみエネルギ理論は自由支持法の試験結果 に近いことを示している(の).上田らは一方向㵶維強化 複合材料に対し，動的設計を行うための簡易計算法を 提案し，ひずみエネルギ理論と比較することで，その 有効性を示している(れ)，著者らもひずみエネルギ理 論をもとに減衰定数を同定する手法を提案し，その有 効性を明らかにしてきた (9)(10)．ひずみエネルギ理論に より減衰定数を求めるためには, 振動試験により得ら れた振動减衰特性から減衰定数を決定するため, 振動 試験から材料そのものの振動減衰特性を正確に把握す る必要があることは言及するまでもない，すなわち， 軽量を特徴としている織維強化複合材料の材料そのも のによるエネルギ損失を得るには，空気などの影響を 十分に考慮する必要がある．しかしながら，複合材料 の振動減衰に及ぼす影響を定量的に評価した研究がほ とんど行われておらず，正確な材料隇衰の測定がなさ れていないのが現状である.

このような背景から，大気圧中と低真空中で振動試 験を行い，空気が振動特性に及ぼす影響を調査するこ 
とを本研究の目的とした，具体的には，低真空中で振 動試験を行うための振動試験法を提案し，大気圧中と 低真空中で振動試験を行い，大気圧が振動特性に及ぼ す影響を評価する，さらに試験により得られた大気圧 中，低真空中での減衰比を目標値として，減衰定数を 同定することで, 複合材料の隇衰定数における大気圧 の影響を明らかにする.

\section{2. ひずみエネルギ理論}

2.1 有限要素法に基づく定式化 第 $n$ 次の減衰比 $\zeta_{n}$ は，最大ひずみエネルギ $U_{n}$ ，消散ひずみエネル ギ $\Delta U_{n}$ より次式で定義される.

$$
\zeta_{n}=\frac{1}{4 \pi} \cdot \frac{\Delta U_{n}}{U_{n}}
$$

ここで最大ひずみエネルギ $U_{n}$ は，要素座標系におけ る応力ーひずみ関係マトリクス $\boldsymbol{D}$ と，ひずみべクト ル $\varepsilon_{n}$ より次式で定義される.

$$
U_{n}=\int_{V} \varepsilon_{n}{ }^{T} D \varepsilon_{n} d V
$$

ここでVは体積を表す。

また消散ひずみエネルギ $\Delta U_{n}$ は次式のようになる.

$$
\Delta U_{n}=\int_{V} \varepsilon_{n}{ }^{T} \psi \boldsymbol{D} \varepsilon_{n} d V
$$

ただし $\psi$ は材料座標系におけるラミナの減衰能マト リクスであり，次式のように定義することができる.

$$
\psi=\left[\begin{array}{lllll}
\psi_{L} & & & & 0 \\
& \psi_{T} & & & \\
& & \psi_{T V} & & \\
& & & \psi_{V L} & \\
0 & & & & \psi_{L T}
\end{array}\right]
$$

ここで $\psi_{L}, \psi_{T}$ は面内変形に関する減衰定数であり， $\psi_{T V}, \psi_{V L}, \psi_{L T}$ は各來標面のせん断変形に関する 減衰定数である. なお，本研究では，一次せん断変形 理論を考虑した板要素により振動減衰モデルの定式化 を行った。

2.2 減裹定数同定手法 著者らは振動試験結果 から、ひずみエネルギ理論をもとに減衰定数を同定す る手法を提案し，その有効性を示してきた ${ }^{(())}$（10本節 では，同定手法の詳細な説明は前報 ${ }^{(9)}$ で記述している ため,ここではその概略について述べる.

誤差関数 $f_{i}(\boldsymbol{x})$ を式（5）により定義する減衰定数 同定問題を考える.ここで $x$ は式（4）における減衰
能マトリクスの対角成分を表すべクトルである. また 振動試験により測定された第 $i$ 次の減衰比 $\zeta_{E i}$ と, $\boldsymbol{x}$ を用いて有限要素解析により算出された第 $i$ 次の減衰 比 $\zeta_{i}(\boldsymbol{x})$ の差を誤差関数 $f_{i}(\boldsymbol{x})$ として, 次式のように 定義する。

$$
f_{i}(x)=\frac{\zeta_{i}(x)-\zeta_{E i}}{\zeta_{E i}}
$$

目的関数 $\varphi(\boldsymbol{x})$ を, $m$ 個の誤差関数 $f_{i}(\boldsymbol{x})$ を用いて次 式で定義する.

$$
\varphi(x)=\sum_{i=1}^{m} f_{i}^{2}(x)
$$

この目的関数 $\varphi(x)$ を最小化する減衰定数を, 非線形 最小二乗法により同定する.

\section{CFRP単層板の振動特性測定}

3.1 振動試験の概要供試材には，炭素繊維 TR30G（三菱レイヨン製）とエポキシからなるプリプ レグシートを用いた，成形後の繊維体積含有率は $53.8 \%$ で，成形後の板厚は $1.05 \mathrm{~mm}$ である．この供試材 から, 長さ $199 \mathrm{~mm}$, 幅 $25 \mathrm{~mm}$ の試験片を, 繊維配向 角が $0^{\circ} ， 30^{\circ} ， 45^{\circ} ， 60^{\circ} ， 90^{\circ}$ の 5 種類となるよう 切り出した. ここで試験片の密度は $1500 \mathrm{~kg} / \mathrm{m}^{3}$ である.

図1に示すように，チャンバ内に加振器を設置し， 加振器上にインピーダンスヘッドを固定する，そして インピーダンスヘッドを介して試験片を取付け，大気 圧中で正弦波掃引加振を行い，周波数応答関数を計測 する. 次にロータリポンプによりチャンバ内を減圧し， 同様に計測を行い，実験モード解析により振動特性を 求めた。そして得られた振動特性を比較することによ り，振動減衰に及ぼす大気圧の影響を調査する，本論 文では，3回の実験の平均値を実験結果として示す.

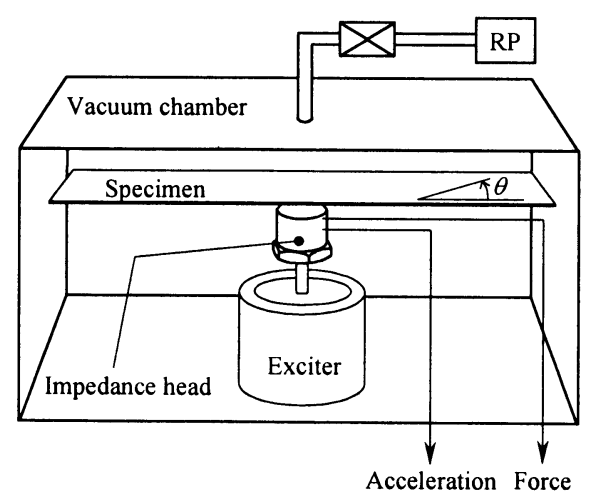

Fig. 1 Experimental setup 
32 試験結果と考察材料自身の減衰特性を測 定する目的で，真空度が振動特性に及ぼす影響を調査 した. 容器内を大気圧から $25 \mathrm{~Pa}$ まで真空度を変化さ せ，加振力一定の条件で振動試験を行った，試験片に は，一方向 CFRPの $0^{\circ}$ 材を用いた.

図 2,3 は $0^{\circ}$ 材の 3 次モードまでの圧力と固有振動 数，減衰比の関係である. 図 2,3 より固有振動数は圧 力にかかわらずほぼ一定值を示すのに対し，減衰比は 大気圧から $10^{3} \mathrm{~Pa}$ まで減少し，その後はほぼ一定にな ることがわかる.ここで, 大気圧から $25 \mathrm{~Pa}$ までの変 化率を $100 \%$ とすると, $10^{3} \mathrm{~Pa}$ における減衰比の変化 率は，1 次から 3 次モードまでそれぞれ 99\%, 94\%, 91\%であった.このことから，減衰比に対する空気の 影響を取り除くには， $10^{3} \mathrm{~Pa}$ 以下で測定する必要があ ることが明らかになった.

次に, 繊維配向角が振動特性に及ぼす影響を調査し た. 3 次モードまでの繊維配向角に対する固有振動数 の測定結果を図 4 に示す．因 4 より繊維配向角 $0 \circ$ の

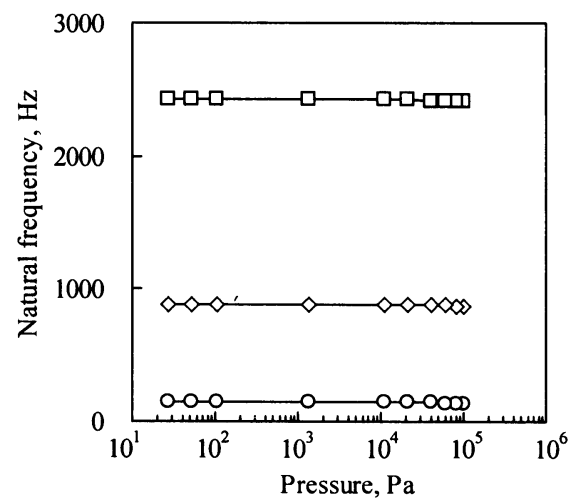

Fig. 2 The effect of pressure in test chamber on natural frequencies $\left(\theta=0^{\circ}\right)$

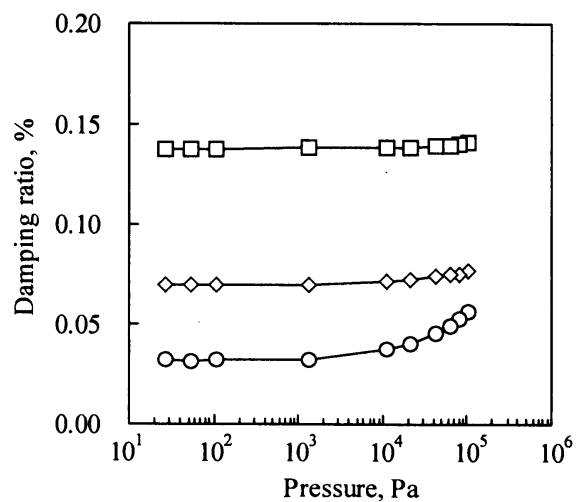

Fig. 3 The effect of pressure in test chamber on the damping ratio $\left(\theta=0^{\circ}\right)$
とき固有振動数が最大となり， $45^{\circ}$ 材まで減少し，そ の後はほぼ一定となることがわかる. 固有振動数は弾 性定数に依存するので，一方向材の織維配向角が弾性 定数に及ぼす影響と同一であることから，これらの結 果となったことは理解できる.

一方，図 5,6は 3 次モードまでの緎維配向角に対す る減衰比の変化を示したものである. 大気圧， $40.0 \mathrm{~Pa}$ 中とも繊維配向角が $0^{\circ}$ から $30^{\circ}$ までの間に減衰比が 急激に大きくなり，その後はほぼ一定の值となる，こ れは $0^{\circ}$ 材では織維が応力を負担するのに対し， $30^{\circ}$ 材以降では，振動減衰能の大きい樹脂が応力を負担す るためであると考える. また次数增加とともに，隇衰 比は大きくなり，せん断の影響が出現していることが 確認できる．また，高次モードほど配向角の影響が少 なくなっている. 振動減衰性能はマトリクスの影響が 支配的であることから，このような結果となったと考 える.

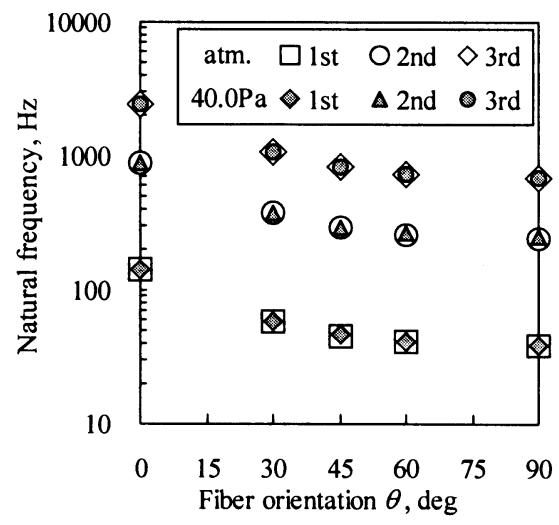

Fig. 4 Variations of natural frequency with fiber orientation

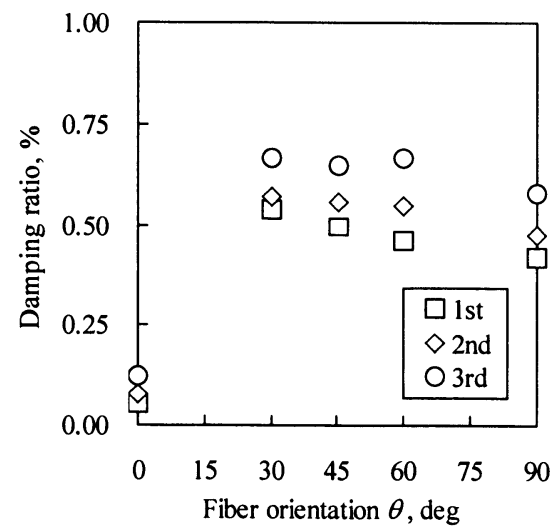

Fig. 5 Variations of damping ratio with fiber orientation (atmosphere) 


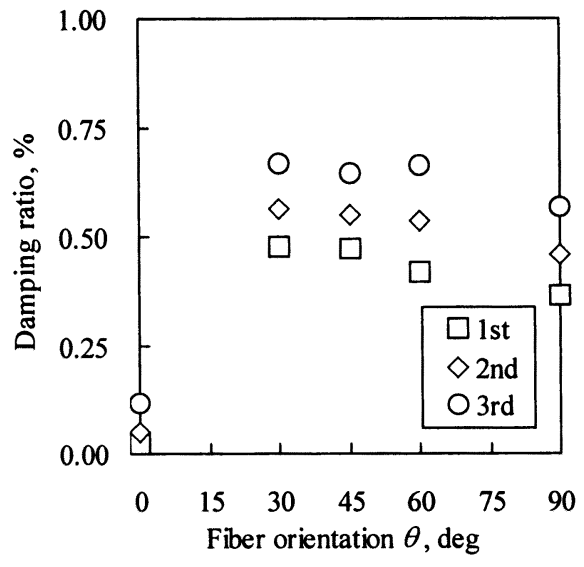

Fig. 6 Variations of damping ratio with fiber orientation $(40.0 \mathrm{~Pa})$

次に圧力の影響について検討するため, 大気圧中 と $40.0 \mathrm{~Pa}$ 中における第 $n$ 次固有振動数 $f_{n}$, 隇衰比 $\zeta_{n}$ の変化を，それぞれ振動特性変化率 $d(f), d(\zeta)$ と して式(7), (8)のように定義し，その変化を求める. 困7，8はその結果である.

$$
\begin{aligned}
& d(f)=\frac{f_{40.0 \mathrm{~Pa}}-f_{\mathrm{atm}}}{f_{\mathrm{atm} .}} \\
& d(\zeta)=\frac{\zeta_{40.0 \mathrm{~Pa}}-\zeta_{\mathrm{atm}}}{\zeta_{\mathrm{atm}}}
\end{aligned}
$$

図 7 より固有振動数は大気圧中よりも $40.0 \mathrm{~Pa}$ 中にお いて常に大きな数值を示したが，その割合は最大でも 1\%以下であることがわかる. また高次モードになる ほど影響が小さくなることが確認できる.

図8より隇衰比は高次に向かうにしたがい，振動減 衰変化率 $d(\zeta)$ が隇少していることがわかる.すなわ ち大気圧が減衰比に及ぼす影響は 1 次モードで約 $60 \%$ と最も大きく，次数とともにその影響は小さくなるこ とが確認できる.

これらのことから，大気圧は固有振動数よりも減衰 比に大きな影響を及ぼすことが確認できた。．またモ一 ドごとに大気圧の影響度が異なる点にも注目する必要 がある.すなわち材料隇衰を評価する祭には各モード に対して，気圧の影響を考虑する必要があると考えら れる.

\section{CFRP単層板の振動特性同定}

大気圧中， $40.0 \mathrm{~Pa}$ 中での試験結果をもとに, CFRP 単層板の減衰定数を同定する.

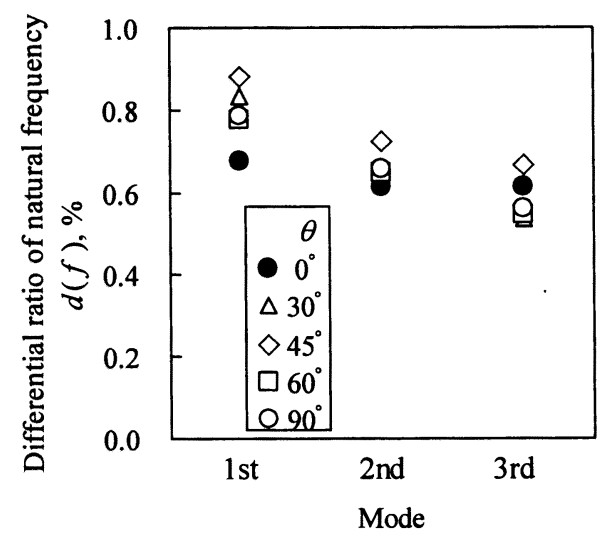

Fig. 7 Relationship between rate of change of natural frequency and fiber orientation

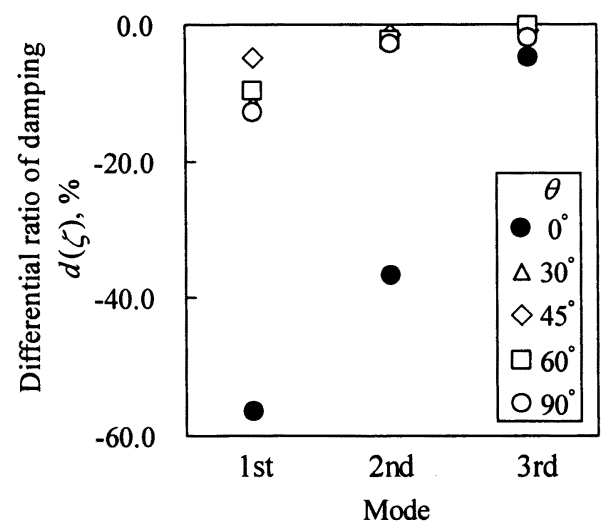

Fig. 8 Relationship between rate of change of damping and fiber orientation

まず，減衰定数を同定するために, CFRP 単層板の 弾性特性を同定する必要がある. そこで試験により得 られた 1 次固有振動数から弾性定数 $E_{L}, E_{T}, G_{L T}$ を直交異方性理論より算出した ${ }^{(2)}$ ．表 1 に示すように 弾性定数に差は見られない. また試験と解析により得 られた固有振動数を比較した結果，大気圧中， $40.0 \mathrm{~Pa}$ 中とも誤差は最大でも $1 \%$ 以下であり，同定した弾性 定数は, CFRP 単層板の弾性特性を十分表現できてい ると考える.

次に, 振動訌験により得られた 1 次モードの減衰比 を目標值として, CFRP 単層板の減衰定数 $\psi_{L}, \psi_{T}$, $\psi_{L T}$ を同定した。ただし瀻維強化方向の特性より $\psi_{T V}=\psi_{V L}=\psi_{L T}$ とした.

因 9,10 はそれぞれ大気圧中および 40.0Pa 中の振動 
試験により測定された減衰比と, 同定した減衰定数を 用いて有限要素解析により算出した減衰比の比較であ る. これより纎維配向角 $0^{\circ} ， 30^{\circ}$ でやや誤差が大き くなっているものの, 各繊維配向角に対する減衰比の 変化が正しく解析されていることが確認できる. また 表 2 より, 纎維方向の減衰定数 $\psi_{L}$ に比して, 織維直 角方向, 面内せん断の減衰定数 $\psi_{T}, \psi_{L T}$ が大きい. すなわち，弾性特性においては繊維の力学的特性が支 配的であるのに対し，振動減衰特性はマトリクスの影 響が支配的であることを表している.これは 32 で考 察した内容とも一致する. さらに表 2 の同定結果より, $\psi_{L}, \psi_{T}$ は, 大気圧中より $40.0 \mathrm{~Pa}$ 中の方が小さい. これは，測定されたモード減衰比が 40.0Pa中の方が小 さいためであると考える. 一方， $\psi_{L T}$ は 40.0Pa中の方 が大きく評価されているが，これは減衰定数同定によ る問題であると考える.このことから，大気圧が減衰 定数に影響を及ぼすことは明らかであるが，減衰特性 の評価にはより詳細な検討が必要と考える.

Table 1 Identified elastic parameters of CFRP lamina

\begin{tabular}{c|ccc}
\hline & $E_{L}$ & $E_{T}$ & $G_{L T}$ \\
\hline atmosphere & 124 & 8.34 & 3.37 \\
$40.0 \mathrm{~Pa}$ & 124 & 8.34 & 3.37 \\
\hline
\end{tabular}

Table 2 Identified damping parameters of CFRP lamina

\begin{tabular}{c|ccc}
\hline & $\psi_{L}$ & $\psi_{T}$ & $\psi_{L T}$ \\
\hline atmosphere & 0.99 & 52 & 7.3 \\
$40.0 \mathrm{~Pa}$ & 0.86 & 4.9 & 8.5 \\
\hline
\end{tabular}

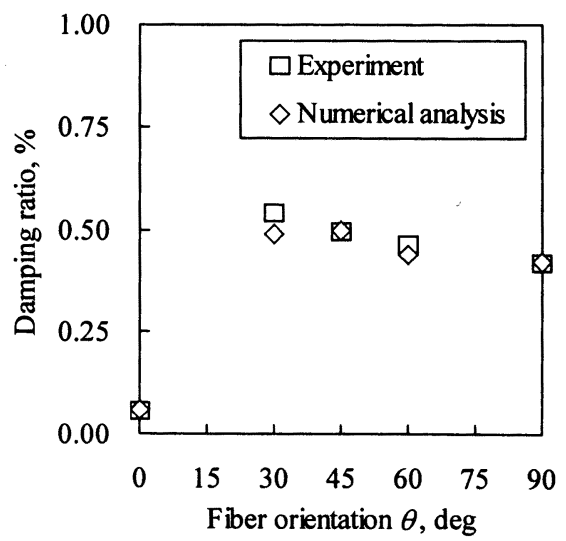

Fig. 9 Comparison of experimental results with numerical results of modal damping ratios of CFRP lamina (atmosphere)

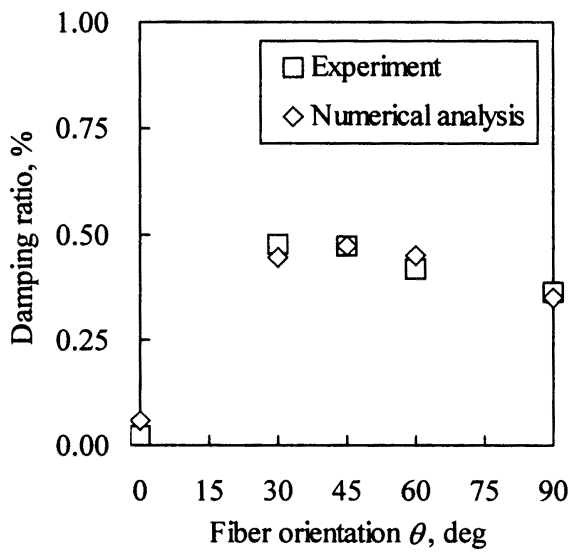

Fig. 10 Comparison of experimental results with numerical results of modal damping ratios of CFRP lamina $(40.0 \mathrm{~Pa})$

\section{5. 結}

本研究では, 空気の減衰効果が振動特性に及ぼす影 響を明らかにするため, 低真空中で試験を行うための 振動試験方法を提案した．そして一方向 CFRP 単層材 に対して大気圧中と低真空中で振動試験を行い，空気 が材料減衰の測定に及ぼす影響を明らかにした．さら に CFRP 単層材の減衰定数を同定した結果，以下の知 見が得られた。

（1）空気が減衰特性に及ぼす影響を取り除くため には，103 Pa以下で振動試験を実施する必要が ある.

（2）大気圧が固有振動数に及ぼす影響は $1 \%$ 程度 であるのに対し，減衰特性に及ぼす影響は最 大で $60 \%$ 程度である.

（3）大気圧の影響は，各モードで異なり，高次モ 一ドになるにつれ影響は小さくなる。

\section{6. 参考文献}

(1) R. Chandra, S. P. Singh, K. Gupta, Damping studies in fiber-reinforced composites - a review, Composites Structures, 46 (1999), 41-51

(2) R D. Adams, Damping Properties Analysis of Composites, Composites (Engineered Materials Handbook Volume 1), (1984), 206-217

(3) D.X. Lin, R. G. Ni, and R. D. Adams, The damping and dynamic moduli of symmetric laminated composite beams - Theoretical and experimental results, Joumal of Composite Materials, 18 (1984), 104-121 
(4) D. X. Lin, R. G. Ni, and R. D. Adams, Prediction and Measurement of the Vibrational Damping Parameters of Carbon and Glass Fibre-Reinforced Plastic Plates, Journal of Composite Materials, 18 (1984), 133-152

（5）青木義男・邊吾一・蓮見薰, CF/PEEK 積層材 のダンピング解析と実験, 材料, 41-466, (1992), $1121-1125$

（6）足立廣正 - 長谷川照夫, 一方向強化 CFRP積層 板における振動減衰能の周波数, 温度特性の 評価, 日本複合材料学会誌, 24-6, (1998), 230237

（7）上田宏樹・井上喜男, 一方向繊維強化プラス チックの減衰特性解析, 機論, 64-619, C (1998), 831-837

（8）上田宏樹・井上喜男, 一方向繊維強化プラス チックの減衰特性解析(動的設計のための簡
易計算法),機論, 66-647,C(2000),2115-2121

（9）松本金矢 - 細川健治 - 座古勝 - 小林博, 積層 複合材料の減衰パラメータ同定法, 機論, 65636, C (1999), 3129-3134

（10）松本金矢・ 中西康雅 - 座古勝, 減衰定数同定 による構造物の減衰比予測, 第 2 回ダンピング シンポジウム講演論文集, (2002), 247-250

(11) N. Alam and T. Asnani, Vibration and Damping Analysis of Fibre Reinforced Composite Material Plates. Journal of Composite Materials, 20 (1986), 2-18

（12）藤井太一・座古勝, 複合材料の破壊と力学 (1978), 実教出版 